\title{
PENGEMBANGAN DAN UJI KELAYAKAN GAME EDUKASI DIGITAL SEBAGAI MEDIA PEMBELAJARAN BIOLOGI SISWA SMA KELAS X PADA MATERI ANIMALIA
}

\author{
Majid Ali Masykhur ${ }^{1}$ \\ Listika Yusi Risnani $^{2}$ \\ 1,2, Pendidikan Biologi Universitas Muhammadiyah Purwokerto \\ E-mail: ${ }^{1}$ majidali.ma2497@gmail.com, ${ }^{2}$ listikayusirisnani@ump.ac.id
}

\begin{abstract}
Science and Technology in education have developed very rapidly in which it requires teachers to carry out integrated learning to technology developments. One of the integrated learning in technology is the use of learning media based on digital educational games. This study aimed to determine the development and feasibility of digital educational games as a learning medium on Animalia material. The model used in this study was the ADDIE development model with the following stages: (1) Analysis, (2) Design, (3) Development, (4) Implementation, and (5) Evaluation. The instruments used in this study were questionnaire and test instruments (pretest-posttest). The questionnaire assessment data were analyzed using quantitative descriptive, while the pre-test, post-test assessment data were analyzed using the N-Gain test. Based on the results of the research, it showed that the assessment of the game by media experts obtained a total score of 3.23 (good category), the assessment by the material expert received a total score of 3.24 (good category), the assessment by the teacher received a total score of 3.3 (very good category), and the assessment by students obtained a total score of 3.56 (very good category). In the implementation of this Animalia Game, it showed an increase in the average pre-test score of 50.19 with an average post-test score of 74.03, and the $\mathrm{N}$-Gain value was 0.47 (moderate category). In conclusion, the digital educational game on Animalia material is suitable for a learning media, however, it has a (moderate) effect on student learning outcomes.
\end{abstract}

Kata Kunci : ADDIE, Game Edukasi Digital, Materi Animalia, Media Pembelajaran

\section{PENDAHULUAN}

Ilmu Pengetahuan dan Teknologi (IPTEK) pada abad ke-21 telah berkembang sangat pesat mempengaruhi berbagai bidang kehidupan manusia, termasuk bidang pendidikan. Tuntutan kurikulum dalam standar proses pendidikan menyatakan bahwa untuk meningkatkan mutu pendidikan yang tinggi perlu adanya pemanfaatan teknologi informasi dan komunikasi melalui proses pembelajaran yang efektif dan efisien (Kemendikbud, 2016; Umam, 2018). Menurut Anshori (2018), proses pembelajaran yang efektif dan efisien dapat terlaksana apabila pesan dan informasi pembelajaran tersampaikan dengan baik kepada siswa. Komponenkomponen dalam pembelajaran yang dapat mendukung terciptanya komunikasi atau penyampaian informasi dengan baik, salah satunya adalah media pembelajaran.

Media pembelajaran merupakan alat bantu yang dapat digunakan oleh guru dalam menyampaikan informasi atau materi pembelajaran kepada siswa di kelas (Muhson, 2010 ; Ariyanto dkk., 2018). 
Penggunaan media pembelajaran bertujuan agar proses pembelajaran menjadi lebih efektif dan efisien, serta tujuan pembelajaran dapat tercapai. Selain itu, pemanfaatan media pembelajaran dapat menarik perhatian dan minat siswa dalam belajar (Nurseto, 2011 ; Ariyanto dkk., 2018). Menurut Munir (2014), media pembelajaran terbagi menjadi 4 jenis yaitu : 1) media audio, 2) media visual, 3) multimedia, dan 4) media benda asli dan orang.

Berdasarkan 4 jenis media pembelajaran tersebut, multimedia menjadi media pembelajaran yang paling efektif dan efisien, sehingga sering digunakan dalam proses pembelajaran di kelas (Putra, 2014). Multimedia pembelajaran adalah media yang menyajikan teks, animasi, gambar, suara, serta video secara bersamaan, dan melibatkan penggunanya untuk berinteraksi serta mengoperasikan media tersebut secara langsung (Putra, 2014; Kurniawati \& Nita, 2018).

Multimedia sebagai salah satu media pembelajaran interaktif, memiliki kelebihan dibandingkan dengan jenis media yang lain. Menurut Husein (2015), multimedia pembelajaran mampu menciptakan proses pembelajaran menjadi lebih menarik, menciptakan suasana kelas yang lebih interaktif, mempersingkat waktu proses pembelajaran, meningkatkan kualitas dan kemampuan penalaran siswa, dan multimedia dapat digunakan dalam proses pembelajaran dimana saja dan kapan saja. Pemanfaatan multimedia secara kreatif dapat membantu tercapainya tujuan pembelajaran yang efektif dan efisien (Kurniawati \& Nita, 2018).

Selama ini multimedia yang banyak digunakan dan dikembangkan oleh guru sebagai media pembelajaran adalah power point. Penggunaan power point sebagai media pembelajaran memungkinkan guru untuk dapat menyajikan teks, gambar, video, dan musik secara bersamaan. Namun penggunaan power point tersebut masih memiliki desain user interface yang terbatas (Nurseto, 2011 ; Tambunan \& Sinuraya, 2014). Hasil penelitian menunjukkan bahwa sebagian besar guru menyusun Power Point secara standar yang disampaikan menggunakan metode ceramah. Hal tersebut menyebabkan proses pembelajaran terpusat pada guru (Teacher Centered Learning), siswa menjadi kurang tertarik pada materi pembelajaran, sehingga aktivitas belajar dan perkembangan intelektual siswa menjadi kurang maksimal (Maesaroh, 2016; Kamil, 2018).

Salah satu solusi untuk mengatasi permasalahan di atas adalah menggunakan multimedia yang mampu menarik minat belajar siswa dengan desain user interface yang menarik, salah satunya adalah game edukasi. Game edukasi merupakan game yang dirancang sebagai media pembelajaran untuk memudahkan penggunanya dalam memahami konsep materi dan memperluas wawasan pengetahuan (Indriana, 2011). Menurut Wibawanto (2018), penyusunan game edukasi memiliki tujuan untuk meningkatkan minat dan motivasi belajar siswa, memberikan siswa pengalaman baru dalam proses pembelajaran, serta meningkatkan pemahaman siswa terhadap materi yang sedang dipelajari. Game edukasi memiliki sejumlah kelebihan, diantaraya: 1) sebagai media pembelajaran interaktif yang menyajikan banyak konten pembelajaran di dalamnya, 2) menarik 
minat siswa dalam mempelajari materi yang diajarkan, 3) dapat dimainkan di PC, Laptop, ataupun Gadget, sehingga dapat digunakan belajar dimana dan kapan saja, 4) dapat meningkatkan pemahaman konsep siswa pada materi yang diajarkan melalui permainan yang menyenangkan (Dwiyono, 2017). Terdapat berbagai jenis game edukasi, salah satunya adalah game edukasi digital.

Game edukasi digital merupakan jenis game edukasi yang pada saat pengoperasiannya menggunakan perangkat digital seperti PC, Laptop, dan Gadget (Pratama, 2017). Pengembangan game edukasi digital perlu ditingkatkan dan dikembangkan lebih lanjut, mengingat adanya kebutuhan siswa terhadap game edukasi digital yang merujuk pada kondisi digital native. Kondisi digital native merupakan kondisi kehidupan siswa yang sudah terbiasa mengakses atau menggunakan teknologi dalam kehidupannya, termasuk dalam proses pendidikan (Risnani \& Adita, 2018). Pengembangan dan implementasi game edukasi digital telah banyak dilaporkan dari berbagai jenjang sekolah, mulai dari jejang SD hingga SMA. Pada jenjang SD pernah dilaporkan oleh Nasikhah dkk., (2016) tentang pengembangan game education pembelajaran PKn materi penghargaan keputusan bersama kelas $\mathrm{V}$ SD. Pada jenjang SMP pernah dilaporkan oleh Risnani dan Adita (2018) tentang pengembangan game edukasi digital untuk meningkatkan minat belajar peserta didik pada mata pelajaran IPA. Pada jenjang SMA pernah dilaporkan oleh Panjaitan dkk,. (2020) tentang pengembangan multimedia interaktif berbasis game edukasi sebagai media pembelajaran materi sistem pernapasan di kelas XI SMA.

Salah satu materi Biologi di kelas $\mathrm{X}$ yaitu materi Animalia. Materi Animalia memiliki ruang lingkup yang cukup luas, mencakup materi klasifikasi taksonomi organisme hingga tatanan pengelompokan organisme pada kingdom Animalia (Maesaroh, 2016). Hasil wawancara yang dilakukan kepada guru Biologi SMA N 1 Kutasari, menyatakan bahwa pembelajaran Biologi khususnya pada materi Animalia merupakan materi yang cukup sulit untuk dikuasai oleh siswa. Selama ini pembelajaran Animalia yang dilakukan berbasis text book, penyajian power point, dan pemutaran video. Hasil dari proses pembelajaran yang demikian menyebabkan siswa cenderung kurang aktif dan kurang tertarik dalam mengikuti proses pembelajaran, sehingga hasil belajar siswa yang diperoleh juga tidak maksimal. Dari permasalahan tersebut diperlukan inovasi pengembangan game edukasi digital pada materi Animalia.

Game edukasi digital sebagai multimedia pembelajaran dikembangkan untuk memenuhi kebutuhan belajar siswa, maka diperlukan adanya uji kelayakan terhadap game edukasi digital yang dikembangkan. Hal tersebut bertujuan untuk mengetahui apakah game edukasi digital tersebut layak digunakan sebagai media pembelajaran siswa. Menurut Anbia (2013), menyatakan bahwa media dapat dikatakan layak jika terdapat 3 komponen penilaian, yaitu 1) komponen kelayakan isi, 2) komponen kelayakan kebahasaan, dan 3) komponen kelayakan penyajian. Uji kelayakan media tersebut dapat diketahui layak atau tidaknya berdasarkan angket penilaian yang telah diisi oleh Ahli Media, 
Ahli Materi, Guru Mata Pelajaran, dan Siswa (Nugroho dkk, 2017).

Rumusan Masalah penelitian ini adalah "Bagaimana tingkat kelayakan game edukasi digital sebagai media pembelajaran Biologi siswa SMA kelas X pada materi Animalia?". Tujuan penelitian ini adalah untuk mengetahui tingkat kelayakan game edukasi digital pada materi Animalia (Hewan) sebagai media pembelajaran di Sekolah Menengah Atas kelas X MIPA.

\section{METODE}

Penelitian ini dilakukan pada bulan Januari - Agustus 2020 yang dilaksanakan di Laboratorium Multimedia Pembelajaran Universitas Muhammadiyah Purwokerto dan SMA N 1 Kutasari Kabupaten Purbalingga. Penelitian ini merupakan jenis penelitian pengembangan dengan produk berupa game edukasi digital pada materi Animalia (Hewan) Sekolah Menengah Atas kelas X. Penelitian ini menggunakan model pengembangan ADDIE. Tahapan proses metode ADDIE sebagai berikut, : 1) Analysis, 2) Design, 3) Development, 4) Implementation, dan 5) Evaluation (Mahardika, 2015 ; Risnani \& Adita, 2018).

$$
\text { Tahapan proses pada }
$$

pengembangan ADDIE, sebagai berikut :

1) Analysis

Analisis dilakukan untuk mengidentifikasi kebutuhan game dalam proses pembelajaran. Ada beberapa tahapan analisis yang dilakukan, yaitu analisis siswa, analisis pengembangan $\mathrm{KD}$ dan indikator, analisis tujuan instruksional, dan analisis media pembelajaran.

2) Design

Berdasarkan Analisis, maka pada tahapan desain ini peneliti melakukan, 1) perancangan materi pembelajaran, 2)

perancangan user interface, 3)

perancangan struktur navigasi, 4)

mendesain asset game.

3) Development

Pada tahap pengembangan ini, dilakukan proses pembuatan dan penyiapan asset game sesuai dengan racangan yang telah ditentukan. Pada tahap ini juga dilakukan penyusunan dan pengembangan game edukasi menggunakan aplikasi "Unity $2 D$ version 2019.4.1f1". Kemudian game yang telah selesai disusun divalidasi oleh ahli media dan ahli materi.

4) Implementation

Pada tahap implementasi, dilakukan uji coba game edukasi digital yang telah dikembangkan kepada siswa. Implementasi game dilakukan kepada 63 siswa kelas X MIPA SMA N 1 Kutasari yang terdiri dari kelas X MIPA 1 dengan jumlah 32 siswa, dan X MIPA 2 dengan jumlah 31 siswa. Pada tahap implementasi juga dilakukan penilaian game oleh guru. Selain itu, pada tahap ini juga dilakukan pemberian soal pre-test dan post-test pada siswa.

\section{5) Evaluation}

Pada tahap ini dilakukan evaluasi terhadap game edukasi digital yang telah dikembangkan. Hal ini bertujuan untuk mengetahui kualitas dan tingkat kelayakan game edukasi yang telah dibuat sebagai media pembelajaran siswa. Evaluasi dilakukan dengan analisis terhadap angket penilaian game dari guru dan siswa.

Instrumen pengumpulan data pada penelitian ini berupa angket yang terdiri dari 35 butir pertanyaan pada angket penilaian ahli media, 25 butir pertanyaan pada angket penilaian ahli materi, 30 butir pertanyaan pada angket penilaian guru, 
dan 35 butir pertanyaan pada angket penilaian siswa. Angket disusun menggunakan skala likert dengan modifikasi 4 skala, yaitu TS (Tidak Setuju), KS ( Kurang Setuju), S (Setuju), dan SS (Sangat Setuju). Instrumen pengumpulan data berupa soal pre-test dan post-test disusun dengan jumlah pilihan ganda sebanyak 20 soal dan essay sebanyak 5 soal. Data yang diperoleh merupakan data hasil penilaian kualitas game oleh ahli media, ahli materi, guru, dan siswa, serta data hasil belajar siswa sebelum dan sesudah menggunakan game edukasi digital.

Teknik analisis data yang digunakan adalah analisis data deskriptif kuantitatif dan deskriptif kualitatif. Analisis data deskriptif kuantitatif digunakan untuk menganalisis data hasil angket tentang kelayakan game edukasi digital berdasarkan penilaian oleh ahli media, ahli materi, guru mata pelajaran, dan siswa. Analisis data kualitatif digunakan untuk menganalisis komentar dan saran dari penilaian game edukasi digital. Berikut ini merupakan langkahlangkah analisis data :

1. Mengubah hasil isian angket yang bersifat kualitatif menjadi kuantitatif dengan skala likert (empat skala).

2. Menentukan rata-rata skor pada setiap item pernyataan berdasarkan pedoman kriteria penilaian sebagai berikut :

Tabel 1. Pedoman Krteria Penilaian game edukasi

\begin{tabular}{|c|l|}
\hline Interval Nilai & Kriteria \\
\hline $\mathrm{Mi}+1,5 \mathrm{Sbi}<\mathrm{X}$ & $\begin{array}{l}\text { Baik } \\
\text { Sekali }\end{array}$ \\
\hline $\mathrm{Mi}+0,5 \mathrm{Sbi}<\mathrm{X} \leq$ \\
$\mathrm{Mi}+1,5 \mathrm{Sbi}$ & Baik \\
\hline
\end{tabular}

\begin{tabular}{|c|l|}
\hline Mi $-0,5$ Sbi $<\mathrm{X} \leq$ \\
$\mathrm{Mi}+0,5 \mathrm{Sbi}$ & Cukup \\
& Baik \\
\hline $\mathrm{Mi}-1,5 \mathrm{Sbi}<\mathrm{X} \leq$ & Kurang \\
$\mathrm{Mi}+0,5 \mathrm{Sbi}$ & Baik \\
\hline $\mathrm{X} \leq \mathrm{Mi}-1,5 \mathrm{Sbi}$ & Tidak \\
& Baik \\
\hline
\end{tabular}

Sumber : Risnani \& Adita, 2018

Keterangan :

$\mathrm{X}$ : rerata skor aktual

Mi : mean ideal

Sbi : simpangan baku ideal

Mi : $1 / 2$ x (skor tertinggi ideal + skor terendah ideal)

Sbi : $1 / 6$ x (skor tertinggi ideal - skor terendah ideal)

Selain itu, analisis data juga dilakukan menggunakan uji $N$-Gain. Uji $N$-Gain dilakukan untuk mengetahui pengaruh game edukasi digital yang telah dikembangkan terhadap hasil belajar Biologi siswa pada materi Animalia. Berikut ini merupakan perhitungan dengan rumus $N$-Gain ternormalisasi yaitu :

$\mathrm{N}-$ Gain $=\frac{\text { Skor } \text { PostTest-Skor PreTest }}{\text { Skor Maksimal Ideal-Skor PreTest }}$

Berikut adalah pedoman pengkategorian nilai indeks $\mathrm{N}$-Gain :

Tabel 2. Kategori Pedoman Penilaian $N$ Gain

\begin{tabular}{|c|c|}
\hline Nilai Indeks Gain & Kategori \\
\hline N-gain $>0.70$ & Tinggi \\
\hline $0.30<$ N-gain $\leq 0.70$ & Sedang \\
\hline N-gain $\leq 0.30$ & Rendah \\
\hline
\end{tabular}

Sumber : Dewi et.al,. 2017

\section{HASIL}

Game edukasi digital yang berjudul "Animalia Game" merupakan game edukasi yang mempresentasikan materi pembelajaran mengenai 
"Animalia" yang telah disesuaikan dengan pembelajaran siswa SMA kelas X MIPA pada mata pelajaran Biologi. Berikut ini merupakan hasil pengembangan game edukasi digital "Animalia Game" menggunakan model pengembangan ADDIE.

\section{Analysis}

Hasil tahap analisis adalah sebagai berikut :

a. Analisis Siswa

Sebagian besar siswa SMA N 1 Kutasari kelas X MIPA 1 dan X MIPA 2 sudah terbiasa menggunakan smartphone dan laptop dalam kehidupan sehari-hari. Selain itu, siswa juga sudah terbiasa bermain game melalui perangkat digital. Penggunaan jenis game digital oleh siswa sudah sangat bervariasi, dari jenis game edukasi digital maupun game non edukasi digital. Namun dari hasil wawancara, menunjukkan bahwa sebagian besar siswa lebih sering bermain game non edukasi digital dibandingkan dengan game edukasi digital. Penggunaan game digital sebagai media pembelajaran masih sangat minim dilakukan dalam proses pembelajaran.

b. Analisis Pengembangan KD dan Indikator

Analisis Pengembangan KD dan Indikator yang dilakukan adalah pada KD 3.9 mata pelajaran Biologi kelas X materi Animalia. Pengembangan Indikator yang dirumuskan untuk mencapai tujuan pembelajaran menggunakan game edukasi sebagai berikut:

Tabel 3. Indikator Pembelajaran

\begin{tabular}{|l|l|}
\hline No. & \multicolumn{1}{|c|}{ Indikator } \\
\hline 1 & $\begin{array}{l}\text { Mengidentifikasi ciri-ciri } \\
\text { umum filum dalam kingdom }\end{array}$ \\
2 & $\begin{array}{l}\text { Animalia. } \\
\text { Menjelaskan habitat, cara } \\
\text { hidup, ciri-ciri hidup, cara }\end{array}$ \\
\hline
\end{tabular}

\begin{tabular}{|l|l|}
\hline 3 & $\begin{array}{l}\text { reproduksi hewan } \\
\text { invertebrata. } \\
\text { Menjelaskan habitat, cara } \\
\text { hidup, ciri-ciri hidup, cara } \\
\text { reproduksi hewan vertebrata } \\
\text { Menjelaskan peranan berbagai } \\
\text { hewan invertebrata dan } \\
\text { vertebrata } \\
\text { Mengelompokkan hewan yang } \\
\text { termasuk golongan } \\
\text { invertebrata dan vertebrata. }\end{array}$ \\
\hline
\end{tabular}

c. Analisis Tujuan Instruksional

Hasil dari analisis ini berupa penjabaran dari tujuan instruksional pada KD 3.9 pada mata pelajaran Biologi kelas X MIPA semester II, sebagai berikut :

Tabel 4. Tujuan Instruksional

\begin{tabular}{|l|lr|}
\hline No & \multicolumn{2}{|c|}{ Tujuan Instruksional } \\
\hline 1 & $\begin{array}{l}\text { Siswa dapat mengidentifikasi } \\
\text { ciri-ciri umum filum pada } \\
\text { kingdom Animalia dengan } \\
\text { benar. } \\
\text { Siswa dapat menjelaskan } \\
\text { habitat, cara hidup, ciri-ciri } \\
\text { tubuh, dan cara reproduksi } \\
\text { hewan invertebrata dengan } \\
\text { benar. } \\
\text { Siswa dapat menjelaskan } \\
\text { habitat, cara hidup, ciri-ciri } \\
\text { tubuh, dan cara reproduksi } \\
\text { hewan vertberata dengan benar. } \\
\text { Siswa dapat menjelaskan } \\
\text { peranan berbagai hewan } \\
\text { invertebrata dan vertebrata } \\
\text { dengan benar. } \\
\text { Siswa dapat mengelompokkan } \\
\text { hewan yang termasuk golongan } \\
\text { invertebrata dan vertebrata } \\
\text { dengan benar. }\end{array}$ \\
\hline
\end{tabular}

d. Analisis Media Pembelajaran

Hasil wawancara menunjukkan bahwa proses pembelajaran Biologi, khususnya pada materi Animalia kelas X 
MIPA di SMA N 1 Kutasari menggunakan media pembelajaran berupa Power Point dan pemutaran video.

\section{Design}

a. Perancangan materi pembelajaran

Tahap ini bertujuan untuk mendesain materi pembelajaran yang relevan sesuai dengan pengembangan indikator dan tujuan instruksional pada materi Animalia. Pokok bahasan pada materi Animalia terbagi menjadi 3 sub yaitu : pengertian umum kingdom animalia, pengelompokkan hewan invertebrata dan pengelompokkan hewan vertebrata. Desain dari rancangan ini sebagai berikut :

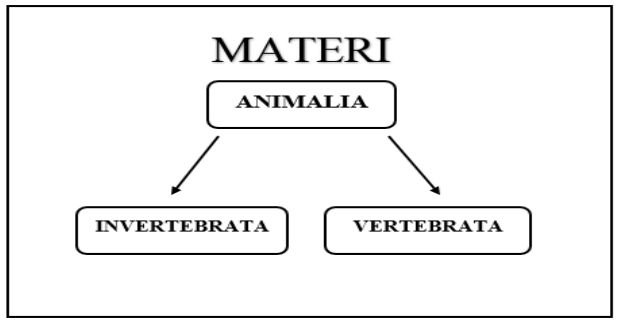

Gambar 1. Desain Materi

b. Mendesain flowchart game

Flowchart merupakan jenis diagram yang mempresentasikan algoritma atau langkah-langkah instruksi yang berurutan dalam suatu sistem. Berikut adalah flowchart yang didesain untuk pengembangan game "Animalia Game" :

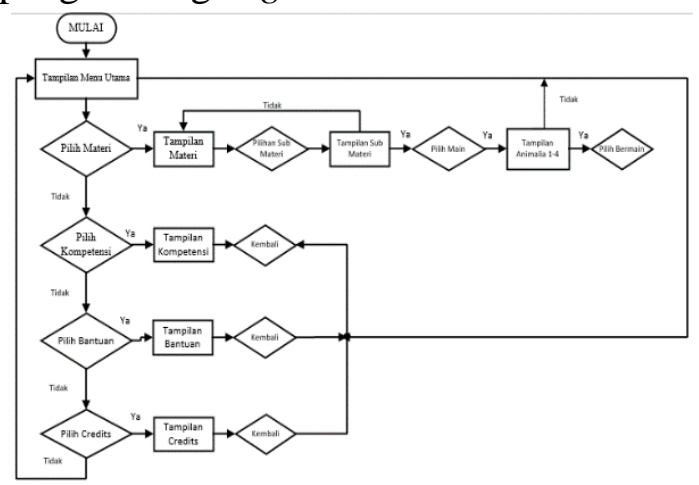

Gambar 2. Desain flowchart

c. Mendesain asset game

Pada tahap ini, peneliti membuat desain dari asset game yang akan dikembangkan. Desain asset game tersebut berupa : background, button (next, back, materi, main, credits, bantuan, kompetensi dan lainnya), gambar hewan, dan musik game.

d. Perancangan user interface

Perancangan user interface bertujuan untuk memudahkan siswa dalam mengoperasikan sistem dalam game. Dalam menentukan desain user interface, peneliti sangat mempertimbangkan aspek estetik visual serta aspek fungsi dari desain tersebut. Desain user interface ini sebagai berikut :

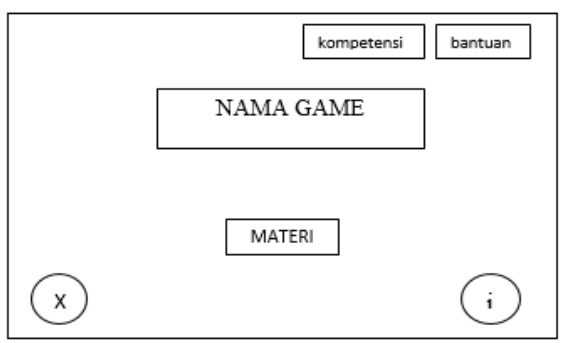

Gambar 3. User Interface

\section{Development}

Berikut ini adalah hasil dari pegembangan "Animalia Game" yang terdiri atas tampilan awal, halaman menu (home), menu materi, halaman main, halaman level game, halaman animalia 14, dan halaman hasil.

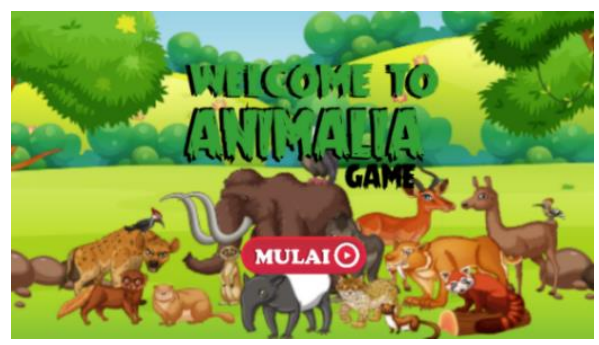

Gambar 4. Tampilan Awal

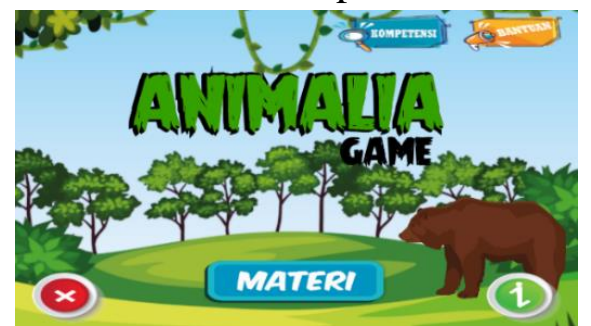




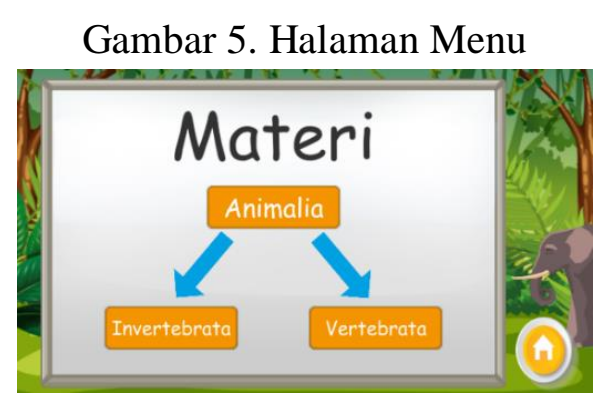

Gambar 6. Halaman Menu Materi

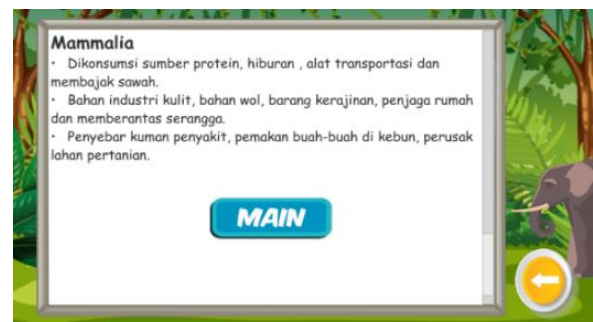

Gambar 7. Halaman Main

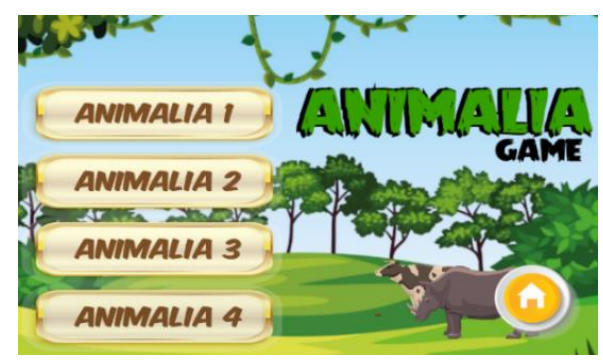

Gambar 8. Halaman Level game

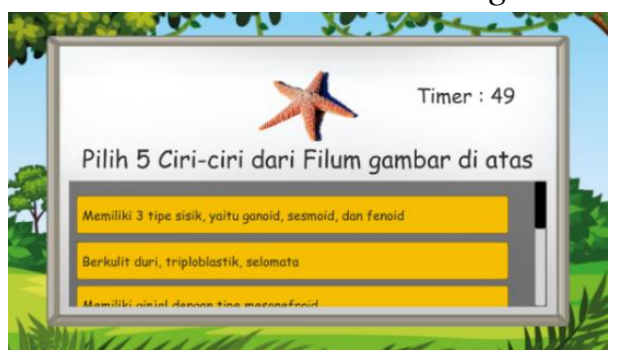

Gambar 9. Halaman Animalia 1

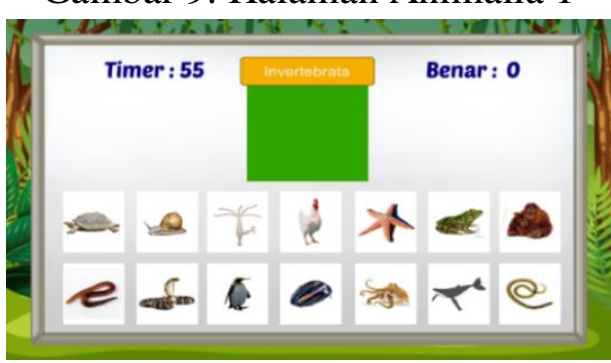

Gambar 10. Halaman Animalia 2

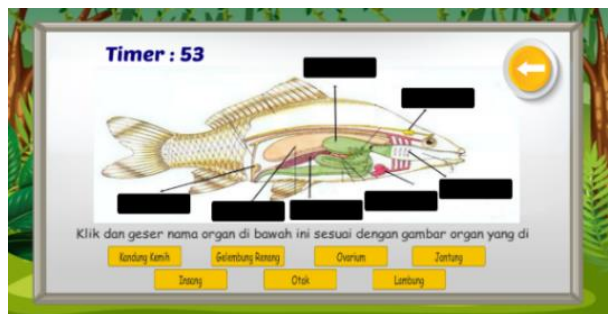

Gambar 11. Halaman Animalia 3

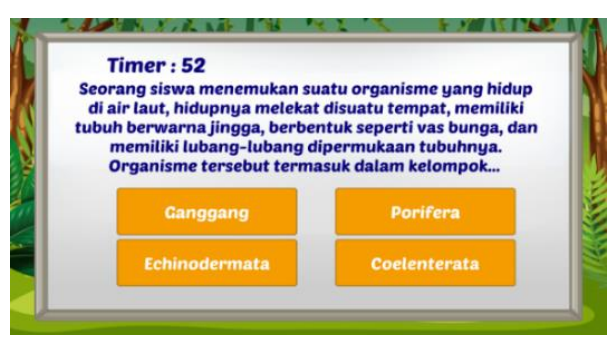

Gambar 12. Halaman Animalia 4

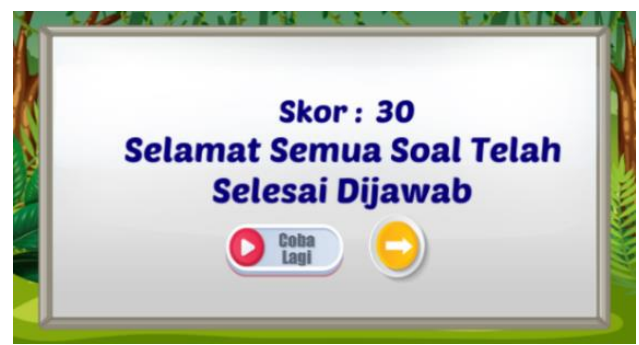

Gambar 13. Halaman Hasil

Pada tahap development juga dilakukan validasi game edukasi digital "Animalia Game" oleh ahli media dan ahli materi dengan hasil sebagai berikut :

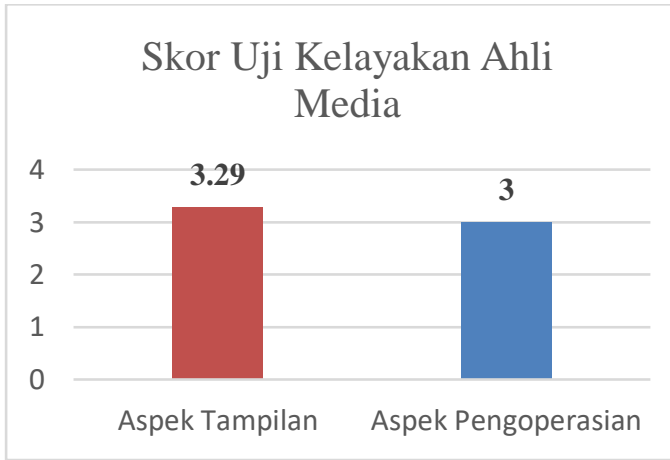

Gambar 14. Grafik Tanggapan Ahli

Media

Hasil uji kelayakan game oleh ahli media menunjukkan bahwa hasil penilaian pada aspek tampilan memperoleh rata-rata skor 3,29 (baik sekali), sedangkan pada aspek pengoperasian memperoleh rata-rata skor 3 (baik). Total penilaian secara keseluruhan memperoleh rata-rata skor 3,23 (baik). 


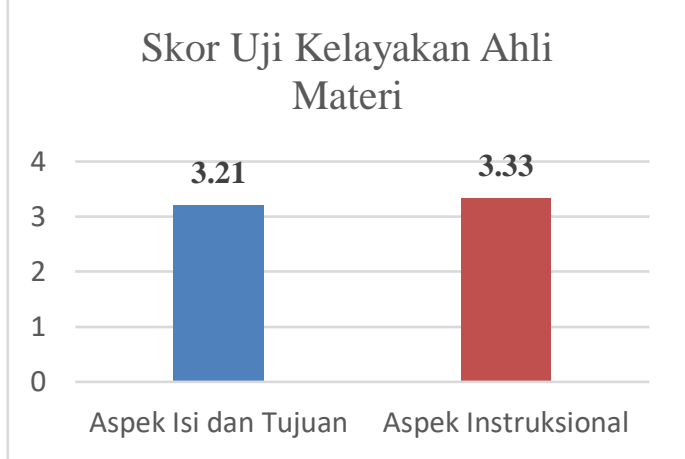

Gambar 15. Grafik Tanggapan Ahli Materi

Hasil uji kelayakan game oleh ahli materi menunjukkan bahwa hasil penilaian pada aspek isi dan tujuan memperoleh rata-rata skor 3,21 (baik), sedangkan pada aspek instruksional memperoleh rata-rata skor 3,33 (baik sekali). Total penilaian secara keseluruhan memperoleh rata-rata skor 3,24 (baik).

\section{Implementation}

Pada tahap implementasi dilakukan penilaian game edukasi "Animalia Game" oleh guru dan siswa SMA N 1 Kutasari kelas X MIPA 1 dan X MIPA 2 dengan total siswa keseluruhan 63 siswa. Hasil implementasi angket yang didapatkan dari penilaian game oleh guru dan siswa sebagai berikut :

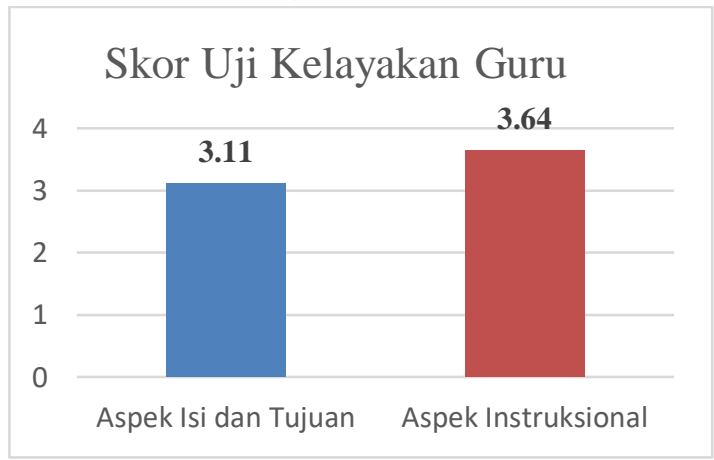

Gambar 16. Grafik Tanggapan Guru

Hasil uji kelayakan game oleh guru Biologi menunjukkan bahwa hasil penilaian pada aspek isi dan tujuan memperoleh rata-rata skor 3,11 (baik), sedangkan pada aspek instruksional memperoleh rata-rata skor 3,64 (baik sekali). Total penilaian secara keseluruhan memperoleh rata-rata skor 3,3 (baik sekali).

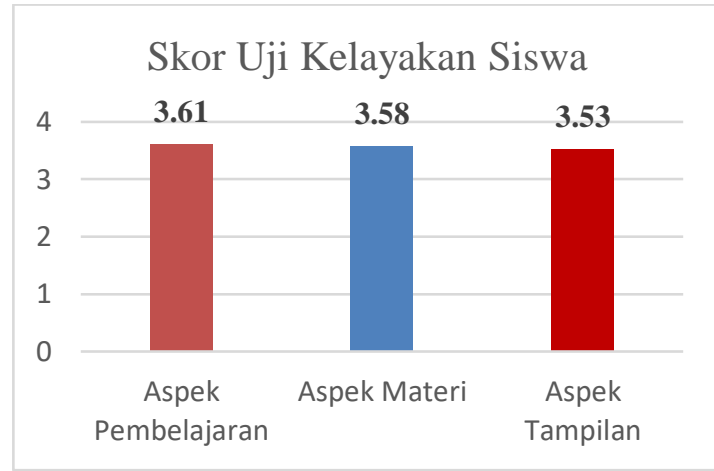

Gambar 17. Grafik Tanggapan Siswa

Hasil uji kelayakan game oleh siswa menunjukkan bahwa hasil penilaian pada aspek pembelajaran memperoleh rata-rata skor 3,61 (baik sekali), pada aspek materi memperoleh rata-rata skor 3,58 (baik sekali), dan pada aspek tampilan memperoleh rata-rata skor 3,53 (baik sekali).

Selain itu pada tahap implementasi juga dilaksanakan pre-test dan post-test dengan hasil sebagi berikut :

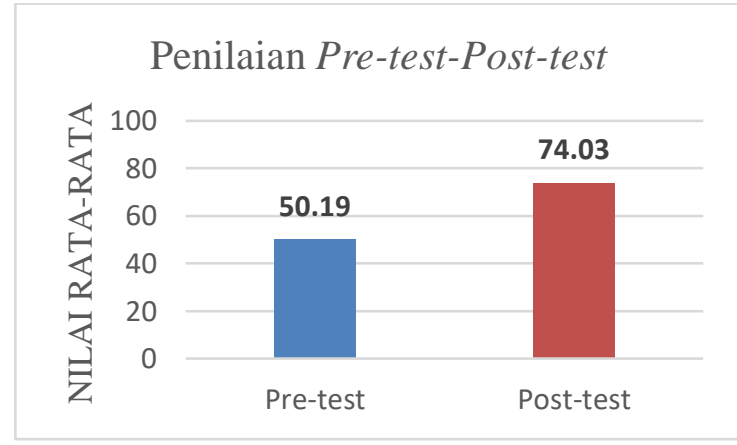

Gambar 18. Grafik Uji N-Gain

Hasil penelitian menunjukkan ratarata nilai pre-test 50,19 dan rata-rata nilai post-test 74,03 . Berdasarkan perhitungan dengan menggunakan uji $N$-Gain diperoleh hasil nilai $\mathrm{N}-$ Gain dengan nilai 0,47 kategori sedang (Tabel 2).

\section{Evaluation}

Pada tahap ini dilakukan evaluasi terhadap game edukasi yang telah dikembangkan, yaitu dengan melakukan evaluasi terhadap hasil penilaian uji 
kelayakan game edukasi digital "Animalia Game” yang dinilai oleh ahli media, ahli materi, guru, dan siswa menggunakan angket. Evaluasi ini digunakan untuk mengetahui tingkat kelayakan game yang dikembangkan.

\section{PEMBAHASAN}

Penelitian ini berhasil mengembangkan game edukasi digital "Animalia Game" sebagai multimedia interaktif menggunakan model pengembangan ADDIE. Game edukasi digital "Animalia Game" dikembangkan berdasarkan desain dan flowchart yang telah ditentukan. Pengembangan game in menggunakan aplikasi Unity $2 D$ version 2019.4.1f1. Game ini memiliki 4 level permainan yang berbeda-beda disesuaikan dengan indikator dan tujuan pembelajaran materi Animalia. Penyusunan dan penggunaan level pada game ini bertujuan agar siswa merasa tertantang dan tertaik untuk memainkannya. Menurut Adita, dkk., 2017), melaporkan bahwa unsur penting dalam pengembangan dan penyusunan game edukasi digital adalah desain yang menarik siswa serta memiliki tantangan tersendiri.

Berdasarkan hasil penelitian, pada tahap pengembangan dilakukan validasi terhadap game edukasi digital. Hasil penilaian kelayakan game yang dilakukan ahli media memperoleh rata-rata skor keseluruhan 3,23 (baik). Hasil penilaian tersebut masuk dalam kategori baik dikarenakan rata-rata skor keseluruhan yang didapatkan berada dalam rentang skor $2,75<\mathrm{X} \leq 3,25$ (Tabel 1).

Ahli media memberikan komentar dan saran perbaikan pada game untuk meningkatkan kualitas game dari segi tampilan, yaitu dari segi kualitas gambar dan desain background yang kontras agar lebih jelas dan lebih menarik. Hal serupa pernah dilaporkan oleh Richardson (2014), yang menyatakan bahwa pemilihan warna yang tepat dan sesuai untuk gambar dan latar belakang dapat meningkatkan minat siswa dalam belajar dan meningkatkan kemampuan siswa untuk mengingat materi yang telah dipelajari. Selain itu, tampilan media pembelajaran yang menarik dan kreatif sangat mempengaruhi proses pembelajaran, semakin menarik tampilan media yang dikembangkan maka siswa semakin termotivasi untuk mengikuti pembelajaran (Resiani, 2015).

Hasil penilaian kelayakan game edukasi digital yang telah dilakukan oleh ahli materi memperoleh rata-rata skor dari keseluruhan aspek yaitu 3,24 (baik). Hasil penilaian tersebut masuk dalam kategori baik dikarenakan rata-rata skor yang didapatkan berada dalam rentang skor 2,75 $<\mathrm{X} \leq 3,25$ (Tabel 1).

Ahli materi juga memberikan komentar dan saran perbaikan memperhatiakan cara penulisan materi dan soal pada game. Selain itu, ahli materi juga memberikan saran untuk menyesuaikan materi pada game dengan kompetensi dasar siswa kelas X pada materi Animalia. Hal serupa pernah dilaporkan oleh Arifin (2018), yang menyatakan bahwa penyusunan materi yang baik dalam media pembelajaran harus disesuaikan dengan kompetensi dasar dan indikator pembelajaran, sehingga memudahkan siswa dalam memahami materi yang dipelajari dan proses pembelajaran menjadi lebih efektif.

Setelah dilakukan validasi game oleh ahli media dan ahli materi, selanjutnya game diuji cobakan pada kegiatan belajar di sekolah. Hal tersebut 
sesuai dengan Noviani (2013) yang menyatakan bahwa berdasarkan penilaian game edukasi digital oleh ahli media dan ahli materi perlu dilakukan perbaikan produk berdasarkan saran perbaikan dari ahli tersebut, jika produk yang telah divalidasi memenuhi kriteria dan tidak perlu diperbaiki lagi (layak), maka game edukasi digital tersebut siap untuk diujicobakan pada siswa di sekolah.

Pada tahap implementasi game dilakukan penilaian oleh guru Biologi dan siswa SMA kelas X MIPA terhadap game menggunakan angket yang diberikan. Berdasarkan hasil penilaian kelayakan game edukasi digital "Animalia Game" oleh guru Biologi kela X MIPA diperoleh skor rata-rata dari keseluruhan aspek yaitu 3,3 (baik sekali). Hasil penilaian tersebut masuk dalam kategori baik sekali dikarenakan rata-rata skor yang didapatkan berada dalam rentang skor $3,25<\mathrm{X}$ (Tabel 1).

Guru juga memberikan komentar positif terhadap penggunaan game "Animalia Game" bahwa game tersebut memudahkan dan membantu guru dalam proses pembelajaran, serta penggunaan game edukasi digital tersebut sebagai media pembelajaran memiliki daya tarik lebih kepada siswa untuk memahami materi yang disampaikan, sehingga pembelajaran menjadi lebih efektif dan efisien. Hal tersebut sesuai dengan pernyataan Kemendikbud (2016), bahwa pemanfaatan teknologi informasi dan komunikasi dalam bidang pendidikan salah satunya dalam penggunaan media pembelajaran, pemanfaatan media pembelajaran diperlukan untuk meningkatkan efesiensi dan efektivitas proses pembelajaran. Selain itu, guru juga memberikan saran terhadap grafis atau desain gambar yang digunakan dalam game agar dapat ditingkatkan lagi.

Selain dilakukan penilaian oleh ahli dan guru Biologi, penilaian game edukasi digital "Animalia Game" juga dilakukan oleh siswa SMA kelas X MIPA yang berjumlah 63 siswa, terbagi menjadi kelas X MIPA 1 dengan jumlah 32 siswa dan kelas X MIPA 2 dengan jumlah 31 siswa. Hasil penilaian game edukasi digital "Animalia Game" yang dilakukan oleh siswa memperoleh skor rata-rata keseluruhan 3,56 (baik sekali). Hasil penilaian tersebut masuk dalam kategori baik sekali dikarenakan rata-rata skor yang keseluruhan yang didapatkan berada dalam rentang skor 3,25 $<\mathrm{X}$ (Tabel 1). Kategori ini didapatkan karena faktor dari antusias siswa dalam mengoperasikan game.

Siswa juga memberikan komentar baik terhadap game tersebut, yaitu game ini menarik dan memberikan pengalaman baru dalam proses pembelajaran, khusunya dalam pembelajaran Biologi materi Animalia. Namun dari hasil penilaian, ada beberapa saran masukan yang diberikan oleh siswa diantaranya adalah soal evaluasi dalam game terlalu sulit, musik yang kurang menarik serta cenderung monoton, petunjuk dalam game kurang jelas, dan perlu adanya penambahan level yang lebih menantang lagi. Menurut Fanny (2013), menyatakan bahwa suatu media pembelajaran yang menarik dan interaktif dapat membantu siswa dalam memahami materi yang disampaikan serta membuat siswa tidak jenuh dan bosan dalam mengikuti pembelajaran.

Pada tahap Implementasi game, menunjukkan bahwa game edukasi digital berpengaruh pada hasil belajar siswa 
dalam kategori sedang. Hasil penelitian ini, sedikit berbeda dengan hasil penelitian sebelumnya yang dilakukan oleh Dania (2020) dan Pambudi (2020) dengan perolehan hasil belajar siswa dalam kategori rendah. Hal ini diduga karena penggunaan game dalam pembelajaran Animalia memberikan pengalaman belajar yang berbeda dan menarik siswa untuk mempelajari materi Animalia. Sehingga hasil belajar siswa akan meningkat. Hal ini sesuai dengan pernyataan Sulistiani (2016) bahwa salah satu faktor yang mempengaruhi hasil belajar siswa adalah motivasi. Selain itu faktor eksternal seperti media pembelajaran yang digunakan oleh guru.

Berdasarkan uji kelayakan game edukasi digital oleh ahli media dan ahli materi, menyatakan bahwa game tersebut berada dalam kategori baik. Sedangkan penilaian oleh guru dan siswa, menyatakan bahwa game tersebut berada dalam kategori baik sekali. Hal tersebut dapat diartikan bahwa game edukasi digital "Animalia Game" layak digunakan sebagai media pembelajaran pada materi Animalia di kelas X MIPA.

Game edukasi digital "Animalia Game" dinyatakan layak digunakan sebagai media pembelajaran karena game tersebut mencakup 3 komponen kualitas kelayakan media, yaitu kelayakan isi dan tujuan, kelayakan kebahasaan, dan kelayakan penyajian/tampilan. Seperti yang dilaporkan Anbia (2013), menyatakan bahwa media dikatakan layak jika memiliki 3 komponen kelayakan, yaitu komponen kelayakan isi dan tujuan, komponen kelayakan kebahasaan, dan komponen kelayakan penyajian.

Selain itu, game edukasi digital "Animalia Game" layak digunakan sebagai media pembelajaran pada era digital natives, karena pada kondisi ini memudahkan siswa untuk mengakses teknologi baik dari laptop maupun smartphone (Risnani \& Adita 2018). Kemudahan akses teknologi ini memberikan kesempatan siswa dalam mencari informasi dan pegetahuan dengan mandiri. Penggunaan game edukasi digital "Animalia Game" ini memfasilitasi siswa dalam mempelajari materi Animalia menggunakan perangkat digital, karena dalam pengoperasiannya game ini dapat diakses melalui laptop, PC, maupun smartphone.

\section{KESIMPULAN}

Berdasarkan hasil penelitian dan pembahasan di atas, maka dapat disimpulkan bahwa : menurut penilaian dari ahli media, ahli materi, guru, dan siswa game edukasi digital "Animalia Game" masuk dalam kategori baik sampai dengan baik sekali sehingga layak digunakan sebagai media pembelajaran di sekolah. Implementasi game edukasi digital memberikan pengaruh (sedang) terhadap hasil belajar siswa pada materi Animalia.

\section{SARAN}

Berdasarkan penelitian yang telah dilakukan, maka disampaikan saran sebagai berikut : 1) Perlu pengembangan lebih lanjut terhadap game edukasi digital yang dapat meningkatkan minat dan hasil belajar siswa pada materi Animalia. 2) Perlu adanya pembiasaan dalam penggunaan game edukasi digital sebagai salah satu inovasi media pembelajaran di sekolah. 3) Perlu diujikan pada siswa di berbagai sekolah yang berbeda. 


\section{DAFTAR RUJUKAN}

Adita, A., Kusuma, A. B., \& Risnani, L. Y. 2017. Analisis Kebutuhan Game Edukasi MIPA. Jurnal BIOEDUKATIKA, 5(2) : 86 - 91

Anbia, W. 2013. Survey Penggunaan Media Pembelajaran pada Mata Pelajaran Ekonomi Materi Akuntansi Kelas XI IPS SMA Negeri 1 Driyorejo Gresik. Jurnal Pendidikan Akuntansi, 1(3) : 1 - 14 Anshori, S. (2018). Pemanfaatan Teknologi Informasi dan Komunikasi Sebagai Media Pembelajaran. Jurnal Ilmu Pendidikan PKn dan Sosial Budaya, : 88 - 100

Arifin, Z. (2020). Pengembangan Media Pembelajaran Audio Visual Adobe Flash Berbasis Android Pada Kompetensi Dasar Konsep Pemasaran Online di Kelas X Pemasaran SMK N 1 Surabaya. Jurnal Pendidikan Tata Niaga, 6(3) : 130-137

Ariyanto, A., Priyayi, D. F., \& Dewi, L. 2018. Penggunaan Media Pembelajaran Biologi Di Sekolah Menengah Atas (SMA) Swasta Salatiga. Jurnal BIOEDUKASI, 9(1) : $1-13$

Dania, D., R. 2020. Pengembangan dan Uji Kelayakan Game Edukasi Digital Sebagai Media Pembelajaran IPA Siswa Kelas VII SMP Pada Materi Klasifikasi Makhluk Hidup. Skripsi. Purwokerto : Universitas Muhammadiyah Purwokerto

Dewi, E. P., Suyatna, A,. Abdurrahman. \& Ertikanto, C. 2017. Efektifitas Modul dengan Model Inkuiri untuk Menumbuhkan Ketrampilan Proses Sains Siswa pada Materi
Kalor. Jurnal Keguruan dan Ilmu Tarbiyah, 2(2) : $105-110$

Dwiyono. 2017. Pengembangan Game Edukasi sebagai Media Pembelajaran Interaktif pada Kompetensi Dasar Mendeskripsikan Peralatan Tangan (Hand Tools) dan Peralatan Bertenaga (Power Tools). Jurnal Program Studi Pendidikan Teknik Mekatronika, 7, 343-351.

Fanny, A. M. \& Sudirman, S. P. 2013. Pengembangan Multimedia Interaktif Untuk Mata Pelajaran IPS Sekolah Dasar Kelas V. Jurnal Prima Edukasia, 1(1) : 1 - 9

Husein, S., Herayanti, L., \& Gunawan. 2015. Pengaruh Penggunaan Multimedia Interaktif Terhadap Penguasaan Konsep dan Ketrampilan Berpikir Kritis Siswa Pada Materi Suhu Dan Kalor. Jurnal Pendidikan Fisika da Teknologi, 1(3), 221 -225

Indriana, D. 2011. Ragam Alat Bantu Media Pengajaran. Yogyakarta: DIVA Press.

Kamil, P. M. 2018. Perbedaan Hasil Belajar Siswa Pada Materi Sistem Pencernaan Pada Manusia Dengan Menggunakan Media Power Point Dan Media Torso. Jurnal Bioedusiana, 3(2), 64-68

Kemendikbud. 2016. Peraturan Menteri Pendidikan dan Kebudayaan Republik Indonesia Nomor 22 Tahun 2016 Tentang Standar Proses Pendidikan Dasar dan Menengah

Kurniawati, I. D., \& Nita, S. 2018. Media Pembelajaran Berbasis Multimedia Interaktif Untuk Meningkatkan Pemahaman Konsep Mahasiswa. 
Jurnal of Computer and Information Technology , 1(2), 68 $-75$

Maesaroh, T., \& Hernawati. 2016. Pengembangan Perangkat Pembelajaran Animalia Menggunakan Identification Cue Card Dalam Kaitannya Dengan Kemampuan Retensi dan Keterampilan Komunikasi Siswa SMA (Studi Pendahuluan). Prosiding Seminar Nasional Pendidikan Biologi dan Saintek ke12016.

Mahardika, G. P. 2015. Digital Game Based Learning dengan Model ADDIE untuk Pembelajaran Doa Sehari-hari. Teknoin, 22, 1-8.

Muhson, A. 2010. Pengembangan Media Pembelajaran Berbasis Teknologi Informasi. Jurnal Pendidikan Akuntansi Indonesia. 8(2) : 1 - 10

Munir, M. 2014. Pengembangan Media Pembelajaran Interaktif Kompetensi Dasar Register Berbasis Inkuiri Terbimbing. Jurnal Pendidikan Teknologi dan Kejuruan, 22 (2) : $184-190$

Nasikhah, A. N., Widihastrini, F., Widodo, S., T. 2016. Pengembangan Game Education Pembelajaran PKn Materi Menghargai Keputusan Bersama Kelas V SD. Jurnal Kreatif. 7(1) : $81-91$

Novian, N. D. 2013. Pengembangan Media Pembelajaran Berbasis Game Sebagai Pendukung Mata Pelajaran Teknologi Informasi dan Komunikasi (TIK) Materi Operasi Dasar Komputer Menggunakan Adobe Flash. Skripsi. Yogyakarta : Universitas Negeri Yogyakarta.
Nugroho, A. C., Khairudin, M., \& Hertanto, D. B. 2017. Rancang Bangun Game Edukasi Sebagai Media Pembelajaran Mata Kuliah Praktik Digital. Jurnal Edukasi Elektro, 1(1) : 92 : 98

Nurseto, T. 2011. Membuat Media Pembelajaran yang Menarik. Jurnal Ekonomi \& Pendidikan. $8(1): 19-35$

Pambudi, A., G. 2020. Pengembangan Game Edukasi Digital Pada Materi Sistem Peredaran Darah Sebagai Media Pembelajaran Di SMP Negeri 5 Purwokerto. Skripsi. Purwokerto : Universitas Muhammadiyah Purwokerto

Panjaitan, R., G., P., Titin., Putri, N., N. 2020. Multimedia Interaktif Berbasis Game Edukasi Sebagai Media Pembelajaran Materi Sistem Pernapasan Di Kelas XI SMA. Jurnal Pendidikan Sains Indonesia. 8 (1) : 141 - 151

Pratama, U. N., \& Haryanto. 2017. Pengembangan Game Edukasi Berbasis Android Tentang Domain Teknologi Pendidikan. Jurnal Inovasi Teknologi Pendidikan, 4(2) : $167-184$

Putra, I. E. 2014. Teknologi Media Pembelajaran Sejarah Melalui Pemanfaatan Multimedia Animasi Interaktif. Jurnal TEKNOIF, 1(2) : $20-25$

Resiani, N. K., Agung. A. A. G., \& Jampel, N. 2015. Pengembangan Multimedia Pembelajaran Interaktif Pada Mata Pelajaran IPS Siswa Kelas VII Semester Genap di SMP N 7 Singaraja Tahun Ajaran 2014/2015. Jurnal Edutech, 3(1) 
Richardson, R. T. 2014. Color and Contrast in E-Learning Design : A Review of the Literature and Recommendations for Instructional Designer and Web Developers. Jurnal of Online Learning and Teaching. 10(4) : $657-670$

Risnani, L.Y., \& Adita, A. 2018. Game Edukasi Digital Untuk Meningkatkan Minat Belahar Peserta Didik Pada Mata Pelajaran IPA. The $8^{\text {th }}$ University Research Colloquium 2018.

Sulistiana. I., R. 2016. Pembelajaran Matematika Materi Perkalian Dengan Menggunakan Media Benda Konkret (Manik-Manik dan Sedotan) untuk Meningkatkan Hasil Belajar Siswa Kelas 2 SD Dinoyo Malang. Jurnal Ilmiah Vicratina. 10(2)
Tambunan, E. R., \& Sinuraya, D. E. 2014. Penerapan Media Power Point untuk Meningkatkan Aktivitas dan Hasil Belajar Pengetahuan Dasar Teknik Bangunan Pada Siswa Kelas $\mathrm{X}$ Program Keahlian Gambar Bangunan SMK Negeri 1 Merdeka Berastagi Tahun Ajaran 2012/2013. Jurnal Pendidikan Teknologi dan Kejuruan. 16(2) : 1 $-13$

Umam, M. K. 2018. Peningkatan Mutu Pendidikan Melalui Manajemen Peserta Didik. Jurnal al-Hikmah. $6(2): 62-67$

Wibawanto, W. 2018. Membuat Bermacam Game Android dengan Adobe Animate. Yogyakarta: Penerbit ANDI.

Wibawanto, Wandah, Nugrahani, Rahina. 2018. Desain Antarmuka (user interface) Pada Game Edukasi. Jurnal Imajinasi, 12(2) : 57 - 64 